\title{
DRUHY NEZHODY A ICH (SEMI)FORMÁLNA REKONŠTRUKCIA ${ }^{1}$
}

LUKÁŠ BIELIK, Katedra logiky a metodológie vied, Filozofická fakulta Univerzity Komenského v Bratislave, Bratislava, SR

BIELIK, L.: Kinds of Disagreement and Their (Semi)Formal Reconstruction FILOZOFIA, 74, 2019, No 9, pp. 690 - 704

\begin{abstract}
The phenomenon of doxastic (epistemic) disagreement pertains to contemporary discussions in epistemology. Moreover, a related notion of the difference of opinion (or standpoints) is at the centre of the theory of argumentation (cf. van Eemeren et al. 2014). In this paper, we propose a broader definition of argument which seems to serve a fruitful theoretical function in classifying different kinds of disagreement (difference of opinion). In particular, along with the well known categories of rebutting and undercutting arguments (cf. Pollock 1995; Besnard - Hunter 2008), we distinguish among various further kinds of disagreement which may be reconstructed by a (semi-)formal aparatus as competing arguments. As a result, we are able to represent not only competing justificatory arguments, but also arguments which underlie competing predictions and explanations. Hence, considerations on disagreement extend beyond the classical cases of counterarguments which have been analysed in the theory of argumentation.
\end{abstract}

Keywords: Argument - Competing arguments - Counterargument - Doxastic / epistemic disagreement - Types of disagreement

\section{1. Úvod}

Osoba A tvrdí, že „Príchod investora X do regiónu Y znížil mieru nezamestnanosti v danom regióne“, zatial' čo osoba $\mathrm{B}$ nesúhlasí a tvrdí, že „Príchod investora $\mathrm{X}$ do regiónu Y v ňom mieru nezamestnanosti nezníziil“. Alebo vedecký tím A používajúci model klimatických zmien M1 predpovedá, že priemerná teplota Zeme sa do konca 21. storočia zvýši o 1,8 až $2,4{ }^{\circ} \mathrm{C}$, zatial' čo vedecký tím B používajúci alternatívny model klimatických zmien M2 predpovedá, že priemerná teplota Zeme sa do konca

\footnotetext{
${ }^{1}$ Ďakujem obom anonymným recenzentom za konštruktívne pripomienky k pôvodnej verzii článku. Pomohli mi tak odstránit' viaceré nedostatky, ktoré som prehliadol.
} 
tohto storočia zvýši o 2,7 až $3,9^{\circ} \mathrm{C}$. V týchto a mnohých podobných situáciách dochádza $\mathrm{k}$ javu, ktorý možno označit' za doxastickú alebo epistemickú nezhodu. ${ }^{2}$

Prípady nezhody podobné tým, ktoré sme práve uviedli, sú v centre pozornosti súčasnej epistemológie nezhody (epistemology of disagreement), a majú zvyčajne túto spoločnú štruktúru: Osoba (skupina osôb) A je presvedčená, že $p$ (je pravda), kde $p$ je propozícia (alebo výrok), zatial' čo osoba (skupina osôb) B je presvedčená, že non-p, respektíve že nie je pravda, že $p$. Navyše sa predpokladá, že obaja aktéri, A aj B, sú (porovnatel'ne) inteligentní a obaja majú prístup $\mathrm{k}$ tým istým relevantným informáciám (Feldman 2006, 217). ${ }^{3}$ Otázka, na ktorú sa viacerí epistemológovia nezhody usilujú nájst' odpoved', znie: Ked' si aktér A uvedomí, že sa nezhoduje s aktérom B v otázke, či $p$ je pravda, ako by mal zareagovat', aby bol (respektíve ostal) racionálny? Mal by si zachovat' svoje presvedčenie, alebo sa zdržat' úsudku, či naopak prijat' alternatívne presvedčenie? (Frances 2014, $87-88)^{4}$

Na druhej strane prístupy súčasnej teórie argumentácie reprezentujú stav (doxastickej, respektíve epistemickej) nezhody medzi (aspoň) dvoma komunikačnými aktérmi vo forme rozdielneho názoru (difference of opinion) alebo stanoviska (standpoint), pričom argumentácia má (obom aktérom) slúžit’ ako prostriedok na rozriešenie rozdielneho názoru (van Eemeren a kol. 2014, 6 - 7, 13 - 16). Konkrétne ak osoba A vyjadrí svoj názor, že $q$ (je pravda, kde $q$ je propozícia, respektíve sémantický obsah prislúchajúci výpovedi osoby A), a osoba B pochybuje, že $q$ (je pravda), prípadne to priamo odmieta, tak A má možnost' (a aj komunikačný záväzok určitého druhu a stupňa) predložit také propozície $p_{l}, \ldots, p_{n}$, ktoré by podporili jeho názor, že $q$, a následne aj osoba $\mathrm{B}$ má priestor na vyjadrenie takých propozícií $r_{1}, \ldots, r_{m}$, ktoré by spochybnili aspoň jeden prvok argumentu predloženého osobou A. Osoba A by zase mohla reagovat' predložením d’alších propozícií, ktoré by mierili aspoň na jeden prvok

\footnotetext{
2 Spojenia doxastická nezhoda a epistemická nezhoda používam v tomto článku rovnocenne. $\mathrm{V}$ oboch prípadoch nimi označujem nezhodu týkajúcu sa názoru na pravdivost' (prípadne pravdepodobnost') určitej propozície $p$, ktorá má vyjadrovat' poznanie. V d'alšom texte sa preto obmedzím na používanie spojenia doxastická nezhoda.

3 V situáciách obsahujúcich nezhodu sa predpokladá aj splnenie d’alších podmienok. Napríklad o aktéroch nezhody sa predpokladá, že obaja majú k dispozícii tie isté dáta, evidenciu, čas (na zaujatie doxastického postoja či vyriešenie úlohy), východiskové poznatky, a že obaja sa nachádzajú v (približne) rovnakých okolnostiach (Frances 2014, 26).

4 Problém nezhody možno formulovat' aj v súvislosti s konaním, hodnotami, náboženskými presvedčeniami či subjektívnym vkusom (pozri napríklad Frances, Matheson 2019; Zouhar 2018). V tomto článku však obmedzujeme našu pozornost' len na prípady nezhody v presvedčeniach či názoroch na určitý empirický stav vecí či na matematické fakty (teda na prípady doxastickej alebo epistemickej nezhody). Navyše druh doxastickej nezhody pripúšt’a aj rozdiel v stupňoch presvedčenia.
} 
argumentu osoby B atd'. ${ }^{5}$ Ak túto úvahu zjednodušíme a zovšeobecníme, tak môžeme povedat', že nezhodu možno v rámci (viacerých prístupov) teórie argumentácie rekonštruovat' ako dvojicu (prípadne n-ticu) argumentov $\left\langle\mathcal{A}_{1}, \mathcal{A}_{2}\right\rangle$, kde $\mathcal{A}_{1}$ je pôvodný argument a $\mathcal{A}_{2}$ je protiargument.

V tomto článku sa pokúsime navrhnút' základnú klasifikáciu viacerých druhov doxastickej nezhody, ktoré možno nájst' v oblasti vedeckého, expertného i filozofického diskurzu. Nazdávame sa, že identifikácia viacerých odlišných druhov nezhody môže obohatit' diskusiu o nezhode či rozdielnom názore, a to ako v prípade epistemológie nezhody, tak aj v prípade teórie argumentácie. Uvedená klasifikácia si však nerobí nároky na úplnost'. Naopak, pripúšt’a d’alšie rozšírenie a spresnenie odlišných kategórií nezhody.

Náš postup bude nasledovný: Najskôr predstavíme základné predpoklady, o ktoré sa pri návrhu klasifikácie druhov nezhody opierame. Patrí k nim špecifická definícia pojmu argument, ktorá sa ukáže ako teoreticky plodná pri následnej analýze druhov nezhody. Zmienime aj základné terminologické skratky a konvencie, ktoré využijeme v d’alšej časti práce. Potom predstavíme vlastný návrh rozlíšenia jednotlivých druhov nezhody, ktorý zapracúva aj niektoré známe prípady z teórie argumentácie. Napokon zovšeobecníme niektoré výsledky a poukážeme na výzvy, pred ktorými stojí skúmanie doxastickej nezhody.

\section{Teoretické predpoklady}

Literatúra, ktorá sa venuje analýze, rekonštrukcii a hodnoteniu argumentov vyjadrených $\mathrm{v}$ prirodzenom alebo odbornom jazyku, rozlišuje dva základné významy termínu ,argument““. Ten prvý sa spája s používaním tohto výrazu v oblasti logiky a jej aplikácie na prirodzený (resp. odborný) jazyk. Napríklad Irving Copi charakterizuje v jednej z klasických učebníc logiky argument ako „'ubovol'ný súbor výrokov, z ktorých o jednom sa tvrdí, že vyplýva z ostatných, ktoré sa považujú za to, čo poskytuje evidenciu v prospech pravdivosti pôvodného výroku. Záver argumentu je ten výrok, ktorý sa tvrdí na základe ostatných výrokov argumentu a tieto ostatné výroky, ktoré sa uvádzajú ako to, čo poskytuje evidenciu alebo dôvody pre záver, sú premisami argumentu“(Copi 1954, 3). Argument je v tomto zmysle určitá výroková (prípadne propozičná) štruktúra, v ktorej možno rozlíšit’ zložku vyjadrujúcu určitú hlavnú tézu (záver), a tiež prvky, ktoré vystupujú ako podpora hlavnej tézy

\footnotetext{
5 Táto charakterizácia je do istej miery zjednodušením rôznych spôsobov, ktorými možno v určitej komunikačnej situácii argumentovat'. K viacerým spresneniam dôjde v tretej časti tohto článku. K rôznym fázam rozriešenia rozdielneho názoru pozri napríklad van Eemeren (2018, kap. 3).
} 
(premisy), pričom uvažovaným vzt'ahom podpory má byt' vzt'ah (logického) vyplývania (zvyčajne však relativizovaný na určitý formálny jazyk, napríklad na jazyk predikátovej logiky prvého rádu).

Na druhej strane v oblasti teórie argumentácie sa možno stretnút's takým významom termínu „argument“, ktorý zohl’adňuje aj niektoré pragmatické faktory komunikačného kontextu, $v$ ktorom ku argumentácii dochádza. Napríklad Groarke uvádza, že:

„[a]rgument pozostáva z aktu odvodenia záveru (an act of concluding), aktu nastolenia premís (an act of premising) a z implicitného alebo explicitného inferenčného slova, ktoré naznačuje, že záver vyplýva z premís“ (Groarke 2017, § 2). ${ }^{6}$

Tento pojem argumentu teda zahŕňa aj rovinu rečových aktov, ktoré sú typické pre vyjadrenie argumentov v určitom komunikačnom kontexte.

Oba významy termínu ,argument" plnia v teoretickom kontexte logiky a teórie argumentácie svoju teoretickú funkciu. Ak sa však chceme pozriet' na rekonštrukciu viacerých druhov nezhody, ktoré nie sú štandardne v centre pozornosti teórie argumentácie (podobne ako aj epistemológie nezhody), no predsa len majú svoje miesto vo vedeckom i mimovedeckom diskurze, potrebujeme zaviest širší pojem argumentu, než je v diskutovaných prístupoch bežné. Ide o pojem, ktorý argument nespája výlučne len s argumentačným ciel'om - teda s ciel’om zdôvodnit' určitú tézu. Pojem argumentu, ktorý navrhujeme, nám okrem iného umožňuje identifikovat' a rekonštruovat' ako argumenty aj predikcie a explanácie určitého druhu. Na druhej strane definícia argumentu, ktorú ponúkame, odhliada od špecifických rečových aktov, ktoré sa vyskytujú v argumentácii.

Analýza rôznych druhov nezhody, ktorú predstavíme v tretej časti článku, sa opiera o nasledujúcu definíciu argumentu.

\section{Definícia argumentu}

Argument $\mathcal{A}$ je postupnost' $<\pi>$ propozícii $\pi_{1}, \ldots, \pi_{\mathrm{n}}$ vyjadrených v jazyku $J$ postupnost'ou $\langle v\rangle$ výrokov $v_{l}, \ldots, v_{n}$ (pre $\left.\mathrm{n} \geq 1\right)$, pre ktorú $(<\pi\rangle$, resp. $\langle v>)$ platí, že:

i) prvky postupnosti $\langle\pi\rangle$, resp. $\langle v\rangle$ možno rekonštruovat' v rámci jazyka $J^{*}$ určitého formálneho alebo semi-formálneho systému $S$ ako inferenčnú reláciu $R^{I}(\phi, Z)$, kde $\phi$ je množina premís a $Z$ je záver (hlavná téza), pričom

6 Podobnú definíciu ponúka aj Hitchcock $(2007,107)$. 
ii) $\phi$ má (mat') v $R^{I}$ vzhl'adom na daný kognitívny komunikačný kontext $K$ aspoň jednu z nasledujúcich funkcií: a) $\phi$ podporuje $Z$; b) $\phi$ je základom predikcie $Z$; c) $\phi$ poskytuje vysvetlenie $Z$; alebo d) $\phi$ je reviziou (nejakej) teórie $T$ na $Z$ (pričom $Z=T^{*}$, kde $T^{*}$ je modifikovaná teória).

Bude vhodné, ak poskytneme stručný komentár k hlavným bodom tejto definície. Všimnime si, že naša definícia pripúšt’a, že argumentom vyjadreným v určitom jazyku $J$ môže byt' rôznorodá postupnost' propozícií, respektíve výrokov, konkrétne aj taká postupnost', v ktorej je hlavná téza (záver) formulovaná ako prvá, prípadne ako posledná, či ako prvok vyskytujúci sa niekde medzi prvým a posledným členom tejto postupnosti, pričom aj premisy môžu byt' takpovediac roztrúsené v širšom textovom (alebo rečovom) kontexte. Podstatné však je - a to vyjadruje bod i) tejto definície že pôvodnú postupnost' propozícií či výrokov východiskového jazyka $J$ možno v inom jazyku $J^{*}$ určitého formálneho alebo semiformálneho systému $S$ rekonštruovat' ako explicitnú inferenčnú reláciu s jasne vymedzenými (doplnenými či modifikovanými) premisami a záverom. Pritom pod formálnym alebo semiformálnym systémom rozumieme jednak rôzne teórie inferenčných relácií, akými sú napríklad predikátová logika prvého rádu či určitý systém pravdepodobnostnej logiky (pozri napríklad Haenni a kol. 2011), ale aj také teoretické prístupy, ktorých ciel’om je poskytnutie adekvátnej analýzy, rekonštrukcie a hodnotenia argumentov prostredníctvom určitých argumentačných schém, pravidiel, princípov či štruktúry nejakého formálneho alebo semiformálneho jazyka. V takom zmysle možno pod formálne a semiformálne systémy zaradit' aj niektoré prístupy teórie argumentácie - napríklad pragma-dialektický prístup amsterdamskej školy (pozri van Eemeren 2018), Waltonovu koncepciu argumentačných schém (pozri Walton 2006; Walton, Reed, Macagno 2008), Pollockovu koncepciu revidovatel'ných argumentov - defeasible arguments - (pozri Pollock 1987; 1991), teoretický rámec abstraktnej argumentácie (porov. Besnard, Hunter 2008) či nástroje takzvanej formálnej epistemológie (Weisberg 2017), ako aj d’alšie prístupy $\mathrm{k}$ analýze deduktívneho i nededuktívneho usudzovania (pozri Kyburg, Teng 2001).

Navyše bod ii) síce nepracuje explicitne s aparátom rečových aktov, ako je to v prípade pragmaticky motivovanej definície argumentu, no kontext použitia argumentu s určitými cielmmi je v tejto definícií obsiahnutý. Napokon bod ii) tejto definície vymedzuje argument ako takú inferenčnú reláciu medzi premisami a záverom, ktorú možno použit' nielen na účely zdôvodnenia či evidencie v prospech určitej (deskriptívnej alebo preskriptívnej) tézy, ale aj na účely vysvetlenia, predikcie (retrodikcie) či zmeny určitej teórie. 
Ked’že chceme predstavit' niektoré kognitívne zaujímavé druhy nezhody nielen na konkrétnych prípadoch, ale aj v rovine ich všeobecnej argumentačnej štruktúry, oprieme sa o pojmový aparát niektorých formálnych teórií. Ide najmä o vybrané pojmy teórie množín, predikátovej logiky (prvého rádu), teórie pravdepodobnosti a formálnej (bayesiánskej) epistemológie. Formalizáciu však používame len do tej miery, do akej nám pomáha vyjadrit' spoločné znaky odlišných inštancií daného druhu nezhody.

Skôr ako pristúpime k jadru nášho návrhu, uved'me ešte terminologické skratky, ktoré využijeme v nasledujúcej časti:

Nech $\boldsymbol{\mathcal { A }}_{1}$ označuje nejaký (východiskový) argument a nech $\boldsymbol{\mathcal { A }}_{2}$ označuje konkurenčný argument (voči argumentu $\mathcal{A}_{1}$ ). Ďalej nech $\left\{\alpha_{i}\right\}$ označuje množinu premís $\alpha_{1}$, $\ldots, \alpha_{\mathrm{n}}$, a $C$ záver argumentu $\mathcal{A}_{1}$, a nech $\left\{\beta_{\mathrm{j}}\right\}$ označuje množinu premís $\beta_{1}, \ldots, \beta_{\mathrm{m}}$, a $\mathrm{C}^{*}$ záver argumentu $\mathcal{A}_{2}$, pre $1 \leq \mathrm{n} \leq \mathrm{m}$. Napokon nech $R$, respektíve $R_{i}$ označuje inferenčnú reláciu medzi $\left\{\alpha_{\mathrm{i}}\right\}$ a $\mathrm{C}$ (alebo $\left\{\beta_{\mathrm{j}}\right\}$ a $\mathrm{C}^{*}$ ), ktorá je definovaná alebo špecifikovaná v určitom (semi)formálnom systéme $S$. To znamená, že premenná $R$ (respektíve jej indexové varianty) tu môže reprezentovat' nielen reláciu logického vyplývania $\mathrm{v}$ určitom logickom systéme, ale aj reláciu pravdepodobnostného vyplývania (pozri Haenni a kol. 2011) či reláciu induktívnej podpory (Weisberg 2017), prípadne iný druh inferenčnej relácie.

Prostredníctvom tohto aparátu môžeme vyjadrit' všeobecnú štruktúru jednotlivých druhov kognitívne zaujímavých nezhôd.

\section{Argumentačná rekonštrukcia druhov nezhody}

Postupne si predstavíme viaceré kognitívne zaujímavé druhy nezhody. Každý druh nezhody uvedieme bud' konkrétnym príkladom páru konkurenčných argumentov, alebo opisom hlavných znakov konkurenčných argumentov, ktoré spadajú pod daný druh nezhody. Následne poskytneme všeobecnú charakterizáciu príslušného druhu nezhody, ktorá vychádza z našej definície argumentu a ktorá sa opiera o pojmy pomocných (formálnych) teórií, zmienených $\mathrm{v}$ predchádzajúcej časti. V prípade, že ide o druh nezhody, ktorý je $\mathrm{v}$ literatúre teórie argumentácie (prípadne, epistemológie nezhody) štandardne rozpoznaný, upozorňujeme na to.

\section{A. Prípad vyvrátenia}

Predstavme si, že osoba A tvrdí nasledujúcu tézu C: „Politická strana X je jasným favoritom bližiacich sa parlamentných volieb.“ Pritom na podporu tejto tézy uvedie túto premisu $\alpha$ : „Prieskum agentúry U ukazuje náskok 6 percentuálnych bodov strany $\mathrm{X}$ oproti druhej najsilnejšej strane Y.“ Avšak osoba B kontruje tvrdením C*: „Politická strana X nie je jasným favoritom blížiacich sa parlamentných volieb." Na podporu svojho tvrdenia uvedie nasledujúcu informáciu $\beta$ : „Najnovší prieskum agentúry 
V ukazuje náskok strany $\mathrm{X}$ oproti strane $\mathrm{Y}$ len na úrovni 1,2 percentuálneho bodu; navyše $\mathrm{v}$ nedávnom prieskume agentúry $\mathrm{W}$ mala strana $\mathrm{Y}$ navrch nad stranou $\mathrm{X}$ o 2 percentuálne body.“

$\mathrm{V}$ tomto prípade máme pred sebou argumentačný pár $\left\langle\mathcal{A}_{1}, \mathcal{A}_{2}\right\rangle$, v ktorom záver druhého argumentu $\mathcal{A}_{2}$ predstavuje negáciu záveru prvého argumentu $\mathcal{A}_{1}$. Ak predpokladáme konzistentnost' množiny premís $\left\{\alpha_{i}\right\}$ argumentu $\mathcal{A}_{1}$ i konzistentnost' množiny premís $\left\{\beta_{\mathrm{j}}\right\}$ argumentu $\mathcal{A}_{2}$, tak je prirodzené, že množina premís prvého argumentu bude odlišná od množiny premís druhého argumentu: $\left\{\alpha_{i}\right\} \neq\left\{\beta_{\mathrm{j}}\right\}$. Nezhoda dvoch aktérov A a B má tak formu explicitnej nezlučitel'nosti dvoch odlišných záverov dvoch argumentov, z ktorých prvý predložila osoba A a druhý osoba B. Vo všeobecnosti môžeme tento druh nezhody zachytit' nasledujúcou štruktúrou:

$$
\mathcal{A}_{1}: R\left(\left\{\alpha_{\mathrm{i}}\right\}, \mathrm{C}\right) ; \mathcal{A}_{2}: R\left(\left\{\beta_{\mathrm{j}}\right\}, \mathrm{C}^{*}\right) ;\left\{\alpha_{\mathrm{i}}\right\} \neq\left\{\beta_{\mathrm{j}}\right\} ; \mathrm{a} \mathrm{C} * \vdash \neg \mathrm{C}
$$

Tento druh nezhody je v Pollockovej teórií revidovatel'ného uvažovania (defeasible reasoning) známy ako prípad vyvracajúceho anulátora (rebutting defeater). ${ }^{7} \mathrm{Na}-$ vyše Besnard, Hunter (2008, 2 a. n.) hovoria priamo o vyvracajúcich argumentoch (rebutting arguments).

\section{B.1. Prípad spochybnenia (1. verzia)}

Vyjdime z nasledujúceho opisu situácie: Pät' osôb podstúpilo meranie svojej výšky a meranie ukázalo takéto hodnoty (v metroch $m$ ): 1,72; 1,69;1,79; 1,70;1,72.Z týchto informácíi (a z informácie o spôsobe výpočtu aritmetického priemeru) osoba A na záver usúdi, že priemerná výška týchto piatich osôb je $\bar{h}=1,72$. Avšak osoba B uvedie nasledujúcu informáciu: „Dve osoby (z tejto skupiny) boli pri meraní obuté v topánkach, jedna v ponožkách a d’alšie dve naboso." Na základe toho B tvrdí, že niektoré z uvedených číselných hodnôt piatich meraní neposkytujú spolahlivú informáciu o výške meraných osôb.

\footnotetext{
${ }^{7}$ Pollock (1987; 1991; a tiež 1995) predstavuje teóriu revidovatel'ného uvažovania (defeasible reasoning) ako teóriu prima facie dôvodov (odlišných od takzvaných rozhodujúcich dôvodov - conclusive reasons) pre prijatie určitej tézy. Informácie, ktoré vedú k revidovaniu usudzovania založeného na prima facie dôvodoch, Pollock nazýva defeaters. Tento termín prekladám do slovenčiny termínom anulátor. Navyše Pollock rozlišuje medzi takzvanými rebutting defeaters a undercutting defeaters. Prvý termín prekladám spojením vyvracajúci anulátor a druhý spojením spochybňujúci anulátor. Pozri viac v Pollock (1995, 38 - 42, a 3. kap.). V českej literatúre sa možno stretnút' s prekladom termínu rebutter, respektíve rebuttal spojením útok na záver (argumentu), zatial' čo termín undercutter sa prekladá ako útok na zdôvodnenie (nejakého presvedčenia); pozri napríklad Picha $(2014,36)$.
} 
Tento prípad nezhody možno generalizovat' a povedat', že záver $C^{*}$ argumentu $\boldsymbol{\mathcal { A }}_{2}$ vyjadruje informáciu, z ktorej možno odvodit' negáciu aspoň jedného prvku množiny premís $\left\{\alpha_{\mathrm{i}}\right\}$ argumentu $\boldsymbol{\mathcal { A }}_{1}$. Vo všeobecnosti tak prípad spochybnenia zachytáva schéma:

$$
\mathcal{A}_{1}: R\left(\left\{\alpha_{\mathrm{i}}\right\}, \mathrm{C}\right) ; \mathcal{A}_{2}: R\left(\left\{\beta_{\mathrm{j}}\right\}, \mathrm{C}^{*}\right) ;\left\{\alpha_{\mathrm{i}}\right\} \neq\left\{\beta_{\mathrm{j}}\right\} ; \text { a } \mathrm{C}^{*} \vdash \neg \alpha_{\mathrm{s}} \text { pre nejaké } \alpha_{\mathrm{s}} \in\left\{\alpha_{\mathrm{i}}\right\}
$$

Tento druh dvojice konfliktných argumentov rozlišujú aj Besnard, Hunter (2008, 2 a n.) a nazývajú ho undercutting argument, ktorý tu prekladáme ako spochybňujúci argument. Je vhodné upozornit', že Pollock $(1991 ; 1995)$ používa vo svojej teórií revidovatel'ného uvažovania spojenie undercutting defeater - teda spochybňujúci anulátor. No jeho kategórii spochybňujúceho anulátora skôr vyhovuje až nasledujúca verzia prípadu spochybnenia.

\section{B.2. Prípad spochybnenia (2. verzia)}

Druh spochybnenia, o ktorom Pollock $(1991 ; 1995)$ uvažuje, možno uviest' miernou úpravou (doplnením) jeho vlastného príkladu: Predstavme si, že osoba A tvrdí $(\alpha)$ : „Predmet x sa mi javí ako červený.“ Táto informácia je pre osobu A prima facie dôvodom na akceptáciu tézy (záveru C): „Predmet x je červený.“ Avšak osoba B poskytne informáciu $\left(\left\{\beta_{\mathrm{i}}\right\}\right)$ : „Predmet $\mathrm{x}$ je osvietený červeným svetlom. A červené svetlo môže spôsobit', že predmety sa javia ako červené, aj ked' červenými v skutočnosti nie sú.“ Osoba B na základe toho tvrdí (záver C*): „To, že sa predmet x javí $\mathrm{v}$ daných okolnostiach ako červený, nie je dobrým dôvodom na prijatie záveru, že x je červený.“Vyjadrené slovami Pollocka: „Spochybňujúce anulátory útočia skôr na spojenie medzi dôvodom a záverom než priamo na záver“ (Pollock 1995, 41).

Ak uvedený príklad zovšeobecníme, štruktúru tohto druhu argumentačnej nezhody môžeme reprezentovat' touto formou:

$$
\mathcal{A}_{1}: R_{k}\left(\left\{\alpha_{\mathrm{i}}\right\}, \mathrm{C}\right) ; \mathcal{A}_{2}: R_{l}\left(\left\{\beta_{\mathrm{j}}\right\}, \mathrm{C}^{*}\right) ;\left\{\alpha_{\mathrm{i}}\right\} \neq\left\{\beta_{\mathrm{j}}\right\} ; \text { a C } \mathrm{C}^{*}-\left(\left\{\alpha_{\mathrm{i}}\right\}, \mathrm{C}\right) \notin R_{k}
$$

V tomto prípade teda vystupuje dvojica argumentov, z ktorých záver druhého argumentu nespochybňuje priamo ani záver, ani premisu (premisy) prvého argumentu. Avšak informácia, ktorú poskytuje druhý argument a ktorú vyjadruje jeho záver, umožňuje tvrdit', že premisy a záver prvého argumentu nie sú v relácií (deduktívnej alebo nededuktívnej podpory) $R_{k}$ tak, ako to predpokladal prvý argument.

Tieto tri druhy nezhody sú v literatúre teórie argumentácie bežne rozpoznané a analyzované ako určité dvojice argumentu a protiargumentu. Otázku, do akej miery 
tieto tri druhy nezhody korešpondujú s modelovými situáciami, ktoré sú predmetom analýzy epistemológie nezhody, ponechávame otvorenú d’alšiemu skúmaniu. ${ }^{8}$

Podstatné však je, že vd’aka definícii argumentu, ktorú sme navrhli v druhej časti tohto článku, môžeme k uvedeným trom druhom nezhody pridat' aj d’alšie druhy, s ktorými sa možno stretnút' vo vedeckom, expertnom i filozofickom diskurze, no ktoré nie sú osobitne predmetom analýzy teórie argumentácie. Ide najmä o nasledujúce kategórie:

\section{C.1. Konkurenčné predikcie (1. verzia)}

Predstavme si, že pracujeme s dvoma odlišnými pravdepodobnostnými modelmi predpovede počasia pre región X. Označme si tieto modely $\mathrm{M}_{1}$ a $\mathrm{M}_{2}$. Vstupné informácie modelu $\mathrm{M}_{1} \mathrm{o}$ aktuálnych podmienkach počasia $\mathrm{v}$ regióne $\mathrm{X}$ a jeho okolí spolu s teoretickými predpokladmi daného modelu vyjadruje množina premís $\left\{\alpha_{i}\right\}$ a jeho záverom je predikcia (C): „Zajtrajšia teplota v regióne X vystúpi na hodnoty 20 až $23{ }^{\circ} \mathrm{C}$.“ Pre jednoduchost' nateraz odhliadnime od faktu, že daná predikcia (záver argumentu $\boldsymbol{A}_{1}$ ) má vlastne pravdepodobnostný charakter, a teda celý záver možno doplnit' na tvrdenie: „Je vysoko pravdepodobné, že zajtrajšia teplota ...". Podobne, predpokladajme, že vstupné informácie modelu $\mathrm{M}_{2} \mathrm{o}$ aktuálnych meteorologických podmienkach v danom regióne, ako aj teoretické predpoklady daného modelu, vyjadruje množina premís $\left\{\beta_{j}\right\}$. A nech záver príslušného argumentu $\boldsymbol{\mathcal { A }}_{2}$ reprezentuje predikcia $\mathrm{C}^{*}$ : „Zajtrajšia teplota v regióne X vystúpi na hodnoty $19^{\circ} \mathrm{C}$ až $24^{\circ} \mathrm{C}$."V prípade takýchto dvoch argumentov $\mathcal{A}_{1}, \mathcal{A}_{2}$ platí, že ich závery - predikcie - nie sú totožné, no napriek tomu ich konjunkcia predstavuje konzistentný výrok. Inak povedané, ide o dva odlišné argumenty, ktorých premisy sú základom pre odvodenie dvoch odlišných - netotožných - predikcií (záverov), avšak oba závery sú konzistentné, a teda oba môžu byt' súčasne pravdivé. V tomto prípade množina predikovaných hodnôt prvého modelu je vlastnou podmnožinou predikovaných hodnôt druhého modelu.

Vo všeobecnosti možno prvú verziu konkurenčných predikcií zachytit’ nasledujúcou schémou:

$\mathcal{A}_{1}: R\left(\left\{\alpha_{\mathrm{i}}\right\}, \mathrm{C}\right) ; \mathcal{A}_{2}: R\left(\left\{\beta_{\mathrm{j}}\right\}, \mathrm{C}^{*}\right) ;\left\{\alpha_{\mathrm{i}}\right\} \neq\left\{\beta_{\mathrm{j}}\right\} ; \mathrm{C} \neq \mathrm{C}^{*} ;$ ale $\mathrm{C} \wedge \mathrm{C}^{*}$ je konzistentný výrok.

\footnotetext{
${ }^{8}$ Dá sa uvažovat' aj o d’alšom rozdelení uvedených troch kategórii nezhody na viaceré poddruhy. Keby sme pracovali s určitým špecifickým modelom argumentácie - napríklad s Toulminovým modelom - ukázal by sa priestor na jemnejšiu klasifikáciu uvedených druhov nezhody. Napríklad, aktéri A a B by mohli súhlasit's tézou (claim) argumentu, mohli by súhlasit' aj s dátami (data) a princípom (warrant), ale nezhodli by sa na podpore (backing), ktorou sa má zdôvodnit' princíp a podobne Pozri Toulmin (1958/2003). Ďakujem anonymnému recenzentovi za upozornenie na túto možnost'.
} 
Ako sme povedali, uvedený druh nezhody zachytáva situácie, ked' závery dvoch argumentov sú síce odlišné, no oba môžu byt' pravdivé. Ak narazíme vo vede či expertnom diskurze na tento druh nezhody, môžeme sa pýtat', ktorý $z$ argumentov, respektíve záverov argumentov máme uprednostnit'.

Nazdávame sa, že v niektorých situáciách môžeme mat' dôvod na uprednostnenie modelu s užším intervalom predikovaných hodnôt, a to aj za cenu zníženia pravdepodobnosti záveru daného argumentu. Naopak, $\mathrm{v}$ iných situáciách môžeme preferovat' alternatívny argument, ktorého predikcia síce obsahuje širšiu škálu predikovaných hodnôt (a môže íst' tak o menej presný odhad), no pravdepodobnost' daného záveru môže byt' vyššia ako v prípade prvého argumentu.

\section{C.2. Konkurenčné predikcie (2. verzia)}

Predpokladajme teraz, že pri predpovedi počasia vychádzame len z jedného pravdepodobnostného modelu M. Ide o model, ktorý pracuje s určitými vstupnými informáciami o aktuálnych meteorologických podmienkach a na základe daných teoretických predpokladov umožňuje odvodit' rôzne predikcie počasia na určitý deň v regióne X. Uvažujme teda, že na základe modelu M možno odvodit' dve predikcie: Predikciu C, ktorá hovorí, že zajtra bude $\mathrm{v}$ regióne $\mathrm{X}$ teplota $\mathrm{v}$ intervale $\mathrm{T} \pm \sigma$, kde $\mathrm{T}$ je priemerná teplota a $\sigma$ je smerodajná odchýlka; a predikciu $\mathrm{C}^{*}$, ktorá hovorí, že zajtra bude v regióne $\mathrm{X}$ teplota $\mathrm{v}$ intervale $\mathrm{T} \pm 2 \sigma$, kde $2 \sigma$ sú dve smerodajné odchýlky. Predikcia $\mathrm{C}$ je odlišná od predikcie $C^{*}$, a aj pravdepodobnost' $r_{1} \in[0,1]$ odhadu teploty vyjadrenej predikciou $\mathrm{C}$ je odlišná od pravdepodobnosti $\mathrm{r}_{2} \in[0,1]$ odhadu teploty vyjadrenej predikciou $\mathrm{C}^{*}$. Inferenčné relácie $R_{k}$, respektíve $R_{l}$ tu môžu zastupovat' funkcie takzvanej podmienenej pravdepodobnosti.

Vo všeobecnosti tak tento prípad konkurenčných argumentov reprezentuje schéma:

$\mathcal{A}_{1}: R_{k}\left(\left\{\alpha_{\mathrm{i}}\right\}, \mathrm{C}\right)=\mathrm{r}_{1} ; \mathcal{A}_{2}: R_{l}\left(\left\{\beta_{\mathrm{j}}\right\}, \mathrm{C}^{*}\right)=\mathrm{r}_{2} ; \mathrm{r}_{1} \neq \mathrm{r}_{2} ;\left\{\alpha_{\mathrm{i}}\right\}=\left\{\beta_{\mathrm{j}}\right\} ; \mathrm{C} \neq \mathrm{C} *$; ale $\mathrm{C} \wedge \mathrm{C}^{*}$ je konzistentný výrok.

Jeden model tak môže poskytnút' odlišné - hoci konzistentné - predikcie. Tento druh nezhody medzi predikciami dvoch argumentov vychádzajúcich z tých istých premís môže viest', podobne ako v prípade nezhody C.2., k otázke kritérií výberu jednej z konkurenčných predikcí́. Nazdávame sa, že aj v tomto prípade možno nájst' situácie, ked' je vhodnejšie pracovat's užším intervalom predikovaných hodnôt, hoci za cenu nižšej pravdepodobnosti danej predikcie, podobne ako možno nájst' iné situácie, 
v ktorých sa ukazuje ako vhodné prijat' širší interval prípustných hodnôt s vy̌šsou pravdepodobnost'ou danej predikcie.

\section{C.3. Konkurenčné predikcie (3. verzia)}

Posledný prípad konkurenčných predikcií, na ktorý upozorníme, je motivovaný známou Goodmanovou ,novou záhadou indukcie“ (porov. Goodman 1983, kap. 3). Predpokladajme, že premisy $\left\{\alpha_{\mathrm{i}}\right\}$ argumentu $\mathcal{A}_{1}$ obsahujú informáciu, že všetky doteraz pozorované smaragdy sú zelené. Záver $\mathrm{C}$ argumentu $\boldsymbol{\mathcal { A }}_{1}$ obsahuje predikciu (generalizáciu), že všetky (nielen doteraz pozorované) smaragdy sú zelené. Na druhej strane nech premisy $\left\{\beta_{\mathrm{j}}\right\}$ argumentu $\mathcal{A}_{2}$ obsahujú rovnakú informáciu, akú vyjadrujú premisy argumentu $\mathcal{A}_{1}$ - teda, že všetky doteraz pozorované smaragdy sú zelené - , a navyše, nech $\left\{\beta_{\mathrm{j}}\right\}$ obsahuje definíciu predikátu ,je zedrý“. Definícia predikátu ,je zedrý“ je pritom takáto: Pre l'ubovol'ný objekt x platí, že x je zedrý práve vtedy, ked' x je pozorovaný pred časovým okamihom $\mathrm{t}$ a $\mathrm{x}$ je zelený, alebo $\mathrm{x}$ je pozorovaný po časovom okamihu t (vrátane) a x je modrý. Navyše predpokladajme, že časový okamih $\mathrm{t}$ leží niekde v budúcnosti (napríklad $\mathrm{t}=1$. 1. 2050). $\mathrm{Z}$ množiny premís $\left\{\beta_{\mathrm{j}}\right\}$ argumentu $\boldsymbol{\mathcal { A }}_{2}$ tak možno odvodit' konkurenčnú predikciu $\mathrm{C}^{*}$, ktorá hovorí, že všetky smaragdy sú zedré. To ale znamená, že konjunkcia konkurenčných záverov $\mathrm{C} \wedge \mathrm{C}^{*}$ nie je konzistentný výrok - inak povedané, nie je možné, aby oba výroky (propozície) C aj $\mathrm{C}^{*}$ boli pravdivé.

Tento prípad možno generalizovat' na samostatný druh nezhody, ktorý reprezentujú nasledujúce podmienky:

$\mathcal{A}_{1}: R\left(\left\{\alpha_{\mathrm{i}}\right\}, \mathrm{C}\right) ; \mathcal{A}_{2}: R\left(\left\{\beta_{\mathrm{j}}\right\}, \mathrm{C}^{*}\right) ;\left\{\alpha_{\mathrm{i}}\right\} \subset\left\{\beta_{\mathrm{j}}\right\} ; \mathrm{C} \neq \mathrm{C}^{*} ;$ a $\mathrm{C} \wedge \mathrm{C}^{*}$ nie je konzistentný výrok.

Nezhoda tohto druhu reprezentuje dvojicu argumentov $\left\langle\mathcal{A}_{1}, \mathcal{A}_{2}\right\rangle$, kde množina premís $\left\{\alpha_{\mathrm{i}}\right\}$ argumentu $\mathcal{A}_{1}$ je vlastnou podmnožinou množiny premís $\left\{\beta_{\mathrm{j}}\right\}$ argumentu $\mathcal{A}_{2}$, a kde nie je možné, aby konjunkcia $\mathrm{C} \wedge \mathrm{C}^{*}$ bola pravdivá.

\section{D.1. Konkurenčné explanácie (1. verzia)}

Prejdime teraz k druhom nezhody, ktoré zahŕňajú prípady argumentov poskytujúcich odlišné vysvetlenia toho istého alebo ekvivalentne opísaného faktu. Predstavme si, že chceme vysvetlit', prečo má Mária zvýšenú teplotu. A teda nech výrok C hovorí: „Mária má zvýšenú teplotu. " Ďalej predpokladajme, že výrok C je totožný (alebo ekvivalentný) s výrokom $\mathrm{C}^{*}$. Osoba A poskytne vysvetlenie faktu, že $\mathrm{C}$ (respektíve $\mathrm{C}^{*}$ ), uvedením informácie $(\alpha)$, že Mária má chrípku, zatial čo osoba B vysvetl'uje fakt, že 
$C^{*}$ (respektíve C), uvedením informácie $(\beta)$, že Mária pred dvoma dňami stála vonku premočená v chladnom daždivom počasí viac ako dve hodiny. Premisy $\left\{\alpha_{\mathrm{i}}\right\}$ argumentu $\mathcal{A}_{1}$ poskytujú odlišné vysvetlenie faktu opísaného výrokom $\mathrm{C}$ (respektíve $\mathrm{C}^{*}$ ) než poskytujú premisy $\left\{\beta_{\mathrm{j}}\right\}$ argumentu $\mathcal{A}_{2}$. Obe vysvetlenia toho istého faktu sú však navzájom konzistentné, teda môže byt' zároveň pravda, že Mária má chrípku, a tiež že Mária zotrvala $v$ chladnom počasí dostatok hodín na to, aby to oslabilo jej organizmus a ona ochorela.

Nezhoda tohto druhu poukazuje na existenciu odlišných kompatibilných vysvetlení, ktoré kladú dôraz na odlišné explanačné faktory. Vo všeobecnosti má tento druh nezhody nasledovnú štruktúru:

$$
\begin{aligned}
& \mathcal{A}_{1}: R\left(\left\{\alpha_{\mathrm{i}}\right\}, \mathrm{C}\right) ; \mathcal{A}_{2}: R\left(\left\{\beta_{\mathrm{j}}\right\}, \mathrm{C}^{*}\right) ; \mathrm{C}=\mathrm{C}^{*} \text { alebo } \mathrm{C} \Leftrightarrow \mathrm{C}^{*} ;\left\{\alpha_{\mathrm{i}}\right\} \neq\left\{\beta_{\mathrm{j}}\right\} ; \text { avšak } \\
& \left\{\alpha_{\mathrm{i}}\right\} \cup\left\{\beta_{\mathrm{j}}\right\} \text { je konzistentná množina (výrokov). }
\end{aligned}
$$

Premisy $\left\{\alpha_{\mathrm{i}}\right\}$, respektíve $\left\{\beta_{\mathrm{j}}\right\}$ poskytujú odlišný explanans pre jedno a to isté (ekvivalentné) explanandum $\mathrm{C}$ (respektíve $\mathrm{C}^{*}$ ). Nezhoda tohto druhu sa tak týka skôr výberu preferovaného opisu explanačných faktov ako otázky, ktoré z explanačných informácií sú pravdivé (ked’že obe sú, alebo môžu byt' pravdivé).

\section{D.2. Konkurenčné explanácie (2. verzia)}

$Z$ dejín vedy sú známe viaceré epizódy, ked' určitý jav (javy) vysvetl’ovali konkurenčné vedecké teórie odlišne. Napríklad opis mechanizmu optických javov odrazu a lomu svetla $\left(\mathrm{C}\right.$, respektíve $\left.\mathrm{C}^{*}\right)$ dokázali v určitom historickom vývoji vysvetlit' aj korpuskulárna teória svetla (reprezentovatel'ná premisami $\left.\left\{\alpha_{\mathrm{i}}\right\}\right)$ aj vlnová teória svetla (reprezentovatel’ná premisami $\left.\left\{\beta_{\mathrm{i}}\right\}\right)$. Až neskorší vývoj ukázal, že vlnová teória môže vysvetlit' aj d’alšie optické javy (ohyb a polarizáciu svetla), pričom konkurenčná teória mala s ich vysvetlením problém. Čo je však podstatné, tieto dve teórie (a samozrejme aj mnohé iné dvojice konkurenčných teórií) sú navzájom nekonzistentné. Inak povedané, korpuskulárna teória poskytuje vysvetlenie optických javov určitej kategórie, ktoré je nezlučitel'né s vysvetlením vlnovej teórie. Podobný príklad konkurenčných teórií predstavovali aj flogistonová a oxidačná teória, ktoré vzájomne nezlučitel'ným spôsobom vysvetl'ovali proces horenia (látok).

Ak tieto historické prípady zovšeobecníme, môžeme si základnú podobu nezhody tohto druhu vyjadrit' schémou:

$\mathcal{A}_{1}: R\left(\left\{\alpha_{\mathrm{i}}\right\}, \mathrm{C}\right) ; \mathcal{A}_{2}: R\left(\left\{\beta_{\mathrm{j}}\right\}, \mathrm{C}^{*}\right) ; \mathrm{C}=\mathrm{C}^{*}$, resp. $\mathrm{C} \Leftrightarrow \mathrm{C}^{*} ;$ avšak $\left\{\alpha_{\mathrm{i}}\right\} \cup\left\{\beta_{\mathrm{j}}\right\}$ nie je konzistentná množina (výrokov). 
Uvedená schéma teda reprezentuje konkurenčné explanácie ako argumentačný pár $<\mathcal{A}_{1}, \mathcal{A}_{2}>$, kde $\mathrm{C}$ je záver argumentu $\boldsymbol{\mathcal { A }}_{1}$ a C* je záver argumentu $\mathcal{A}_{2}$, pričom explanans $\mathcal{A}_{1}$ reprezentujú premisy $\left\{\alpha_{\mathrm{i}}\right\}$ a explanans $\mathcal{A}_{2}$ zase premisy $\left\{\beta_{\mathrm{j}}\right\}$.

Okrem doteraz uvedených kategórií nezhody možno v prípade konkurenčných argumentov uvažovat' aj o d'alších druhoch nezhody, ktoré sa týkajú bud' inferenčnej relácie $R^{I}$, alebo párov argumentov, ktorých zložky (premisy, záver alebo relácia medzi nimi) sú modelované teóriou pravdepodobnosti (a d’alšími princípmi formálnej epistemológie). Ked’že sa im na tomto mieste nemáme možnost' detailne venovat', uved'me aspoň ich všeobecnú východiskovú charakterizáciu.

$\mathrm{V}$ prípade dvoch konkurenčných argumentov $<\boldsymbol{\mathcal { A }}_{1}, \boldsymbol{\mathcal { A }}_{2}>$ možno uvažovat' o viacerých variantoch konkurenčných inferenčných relácií. Ich najvšeobecnejšiu formu zachytáva schéma:

$$
\mathcal{A}_{1}: R_{k}\left(\left\{\alpha_{\mathrm{i}}\right\}, \mathrm{C}\right) ; \mathcal{A}_{2}: R_{l}\left(\left\{\beta_{\mathrm{j}}\right\}, \mathrm{C}^{*}\right) ; \text { pričom } R_{k} \neq R_{l} .
$$

Môže íst' napríklad o dva argumenty, ktoré majú spoločné tie isté premisy i totožný záver, avšak relácia prvého argumentu je reláciou výrokovologického vyplývania, kým relácia druhého argumentu je reláciou predikátovologického vyplývania. Môžeme pritom uvažovat' podmienky, za ktorých platí, že záver síce výrokovologicky nevyplýva z daných premís, no vyplýva z nich vzhl’adom na reláciu predikátovologického vyplývania. Prípustné sú, samozrejme, viaceré d’alšie varianty tejto triedy nezhôd.

Okrem toho ak dvaja aktéri A a B modelujú odlišnú mieru svojich presvedčení o určitej propozícii $\pi_{\mathrm{i}}$ prostredníctvom pravdepodobnostnej funkcie $\operatorname{Pr}_{\mathrm{X}}$, ktorá je $\mathrm{v}$ súlade $\mathrm{s}$ teorémami teórie pravdepodobnosti, tak ich odlišné stupne presvedčenia vo vzt’ahu $\mathrm{k}$ určitej téze $\mathrm{C}, \mathrm{kde} \mathrm{C}=\mathrm{C}^{*}$ alebo $\mathrm{C} \Leftrightarrow \mathrm{C}^{*}$, respektíve vo vzt’ahu $\mathrm{k}$ určitej téze $\mathrm{C}\left(\mathrm{C}^{*}\right)$ za predpokladu, že je pravda $\left\{\alpha_{\mathrm{i}}\right\}$, respektíve za predpokladu, že je pravda $\left\{\beta_{\mathrm{j}}\right\}$, možno vyjadrit' takto:

$$
\begin{aligned}
& \text { Aktér A: } \operatorname{Pr}_{A}(C) \text {, resp. } \operatorname{Pr}_{A}\left(C \mid\left\{\alpha_{i}\right\}\right) \\
& \text { Aktér B: } \operatorname{Pr}_{B}\left(C^{*}\right) \text {, resp. } \operatorname{Pr}_{B}\left(C^{*} \mid\left\{\beta_{j}\right\}\right) \text {; pričom: } \\
& \operatorname{Pr}_{A}(C) \neq \operatorname{Pr}_{B}\left(C^{*}\right) \text { alebo } \operatorname{Pr}_{A}\left(C \mid\left\{\alpha_{i}\right\}\right) \neq \operatorname{Pr}_{B}\left(C^{*} \mid\left\{\beta_{j}\right\}\right) .
\end{aligned}
$$

Aktéri A a B sa tak líšia bud' v takzvaných východiskových (nepodmienených) pravdepodobnostiach (pokial' ide o rovnakú tézu), alebo v takzvaných následných pravdepodobnostiach, pričom možno uvažovat' také prípady, ked' $\left\{\alpha_{\mathrm{i}}\right\} \neq\left\{\beta_{\mathrm{j}}\right\}$, ako aj prípady, ked' $\left\{\alpha_{\mathrm{i}}\right\}=\left\{\beta_{\mathrm{j}}\right\}$. 
Detailné predstavenie modelovania viacerých druhov nezhôd v rámci teórie pravdepodobnosti, doplnenej o určité epistemické princípy, presahuje rozsahové možnosti tejto práce. Základnú predstavu o modelovaní stupňov presvedčenia týmto spôsobom a oboznámenie s princípmi formálnej (bayesiánskej) epistemológie čitatel' získa napríklad v prácach Weisberg (2017) či Pettigrew, Weisberg (2019).

Analyzované i naznačené druhy nezhôd, ktoré sme v tejto časti priblížili, predstavujú prípady kognitívne zaujímavých a často sa objavujúcich nezhôd, ktoré možno nájst' vo vedeckom, expertnom i filozofickom diskurze. Projekt návrhu kognitívne zaujímavých druhov nezhody pripúšt’a jednak rozpracovanie ostatných dvoch kategórií nezhody, ktoré sme vyššie zmienili len vo vel'mi všeobecnej podobe (teda triedu konkurenčných inferenčných relácií i triedu odlišných funkcií pravdepodobnosti, ktoré možno použit' na modelovanie [odlišných] stupňov presvedčenia aktérov), jednak tiež doplnenie d’alších schém a verzií už zmienených kategórií.

\section{Perspektíva}

Problematika doxastickej nezhody stojí v centre pozornosti súčasnej epistemológie, no má svoj doplnok aj vo viacerých prístupoch teórie argumentácie. V tejto práci sme navrhli takú definíciu argumentu, ktorá nám pomohla identifikovat' aj také druhy nezhody, ktoré síce nie sú štandardne predmetom analýzy ani epistemológie nezhody ani teórie argumentácie, no možno sa s nimi stretnút v kontexte vedeckého i mimovedeckého diskurzu. Klasifikácia druhov nezhôd, ktorú sme tu predstavili, tak umožňuje reprezentovat' nielen prípady tých konkurenčných argumentov, $v$ ktorých ide o zdôvodnenie či revíziu určitých presvedčení, ale pokrýva aj situácie, v ktorých má zmysel hovorit’ o konkurenčných predikciách či konkurenčných vysvetleniach.

Otázka vzt'ahu medzi uvedenou klasifikáciou a aktuálnou diskusiou v epistemológii nezhody je príliš komplexná na to, aby sme sa na obmedzenom priestore pokúsili dat' na ňu čo i len čiastočnú odpoved'. Myslíme si však, že adekvátnu odpoved' môžeme poskytnút' až vtedy, ked’ si pripravíme adekvátny konceptuálny aparát, ktorý premostí tieto dve síce súvisiace, no predsa len odlišné oblasti. V tomto článku sme sa pokúsili urobit' prvé kroky týmto smerom. Potrebujeme však uskutočnit' d’alšiu nadväzujúcu analýzu, ktorá by priniesla odpoved’ na otázku, v čom sa tieto prístupy $\mathrm{k}$ rekonštrukcii a reprezentácii nezhody líšia, a ktoré znaky majú spoločné.

\section{Literatúra}

BESNARD, P., HUNTER, A. (2008): Elements of Argumentation. Cambridge (Mass.) - London: The MIT Press.

COPI, I. M. (1954): Symbolic Logic. New York: The Macmillan Company.

FELDMAN, R. (2006): Epistemological Puzzles about Disagreement. In: Hetherington, S. (ed.): Epistemology Futures. Oxford: Clarendon Press, 216 - 236. 
FRANCES, B. (2014): Disagreement. Cambridge: Polity Press.

FRANCES, B., MATHESON, J. (2019): Disagreement. In: Zalta, E. N. (ed.): The Stanford Encyclopedia of Philosophy (Fall 2019 Edition).

Dostupné na: <https://plato.stanford.edu/archives/fall2019/entries/disagreement/>

GOODMAN, N. (1983): Fact, Fiction, and Forecast. 4th ed. Cambridge (Mass.) - London: Harvard University Press.

GROARKE, L. (2017): Informal Logic. In: Zalta, E. N. (ed.): The Stanford Encyclopedia of Philosophy (Spring 2017 Edition). Dostupné na: <https://plato.stanford.edu/archives/spr2017/entries/logic-informal/>.

HAENNI, R., ROMEIJN, J-W., WHEELER, G. \& WILLIAMSON, J. (2011): Probabilistic Logics and Probabilistic Networks. Springer.

HITCHCOCK, D. (2007): Informal Logic and the Concept of Argument. In: Jacquette, D. (ed.): Philosophy of Logic. Handbook of the Philosophy of Science. Vol. 5. Elsevier, 101 - 129.

KYBURG, H. E.,- TENG, Ch. M. (2001): Uncertain Inference. Cambridge: Cambridge University Press.

PETTIGREW, R. - WEISBERG, J. (eds.) (2019): The Open Handbook of Formal Epistemology. An open access publication of The PhilPapers Foundation.

Dostupné na: <https://jonathanweisberg.org/pdf/open-handbook-of-formal-epistemology.pdf>

PICHA, M. (2014): Kritické myšlení a rekonstrukce argumentu. Brno: Masarykova univerzita.

POLLOCK, J. (1995): Cognitive Carpentry. A Bradford Book, The MIT Press.

POLLOCK, J. (1991): A Theory of Defeasible Reasoning. International Journal of Intelligent Systems, Vol. 6, 33-54.

POLLOCK, J. (1987): Defeasible Reasoninig. Cognitive Science, 11, 481 - 518.

TOULMIN, S. (1958/2003): The Uses of Argument. Updated edition. New York: Cambridge University Press.

VAN EEMEREN, F. H. (2018): Argumentation Theory: A Pragma-Dialectical Perspective. Springer International Publishing AG.

VAN EEMEREN, F. H., GARSSEN, B., KRABBE, E. C. W., HENKEMANS, A. F. S., VERHEIJ, B., WAGEMANS, J. H. M. (2014): Handbook of Argumentation Theory. Dordrecht - Heidelberg New York - London: Springer.

WALTON, D. (2006): Fundamentals of Critical Argumentation. Cambridge: Cambridge University Press.

WALTON, D., REED, C., MACAGNO, F. (2008): Argumentation Schemes. Cambridge: Cambridge University Press.

WEISBERG, J. (2017): Formal Epistemology. In: Zalta, E. N. (ed.): The Stanford Encyclopedia of Philosophy (Winter 2017 Edition). Dostupné na: <https://plato.stanford.edu/archives/win2017/entries/formal-epistemology/s.

ZOUHAR, M. (2018): Conversations about Taste, Contextualism, and Non-Doxastic Attitudes. Philosophical Papers 47, No. 3, 429 - 460. DOI: https://doi.org/10.1080/05568641.2018.1450159

Práca na tomto článku bola podporená projektom č. APVV-17-0057a projektom VEGA č. $1 / 0036 / 17$.

Lukáš Bielik

Katedra logiky a metodológie vied

Filozofická fakulta UK v Bratislave

Gondova 2

81499 Bratislava

Slovenská republika

e-mail: lukas.bielik@uniba.sk

ORCID ID: https://orcid.org/0000-0002-3918-8392 